\title{
Measurement and Evaluation of the Operating Efficiency of China's Basic Pension Insurance: Based on Three-Stage DEA Model
}

\author{
Zhiguang $\mathrm{Li} \mathbb{D}^{\prime}$ \\ Xu Si ${ }^{1}$ \\ Zhiyuan Ding $\mathbb{D}^{\prime}$ \\ Xiao $\mathrm{Li}^{1}$ \\ Shuai Zheng' \\ Yuxin Wang' \\ Hua Wei ${ }^{1}$ \\ Yige Guo (iD ${ }^{2}$ \\ Wei Zhang ${ }^{3}$
}

'School of Economics and Management, Anhui University of Chinese Medicine, Hefei, Anhui, People's Republic of China; ${ }^{2}$ King's Business School, King's College London, London, UK; ${ }^{3}$ School of Information Engineering, Anhui University of Chinese Medicine, Hefei, Anhui, People's Republic of China
Correspondence: Hua Wei

School of Economics and Management, Anhui University of Chinese Medicine, Hefei, Anhui, People's Republic of China Tel +86 55I-68I29006

Email weihua@ahtcm.edu.cn

Wei Zhang

School of Information Engineering, Anhui University of Chinese Medicine, Hefei,

Anhui, People's Republic of China

Tel +86 55I-68I29224

Email zhangwei900316@I63.com
Purpose: This paper aims to measure the operating efficiency of China's basic pension insurance from 2014 to 2019 in 31 provinces.

Methods: The three-stage DEA model was used to evaluate the operating efficiency of basic pension insurance in 31 provinces.

Results: On the whole, the operating efficiency of China's basic pension insurance was at a high level, but there was still room for improvement. GDP, urbanization level and scale of government public expenditure had a positive impact on the operating efficiency of regional basic pension insurance. In contrast, the old-age dependency ratio had a significant negative effect. There were noticeable regional differences in the operating efficiency of China's basic pension insurance, which showed a pattern of Central $(0.742)>$ Eastern $(0.689)>$ Western (0.505) after removing the influence of environmental variables.

Conclusion: This study systematically analyzes the impact of external environmental regulations on China's basic pension insurance's operating efficiency and provides decisionmaking references for further improving the operating efficiency of China's basic pension insurance. In order to further optimize the allocation of basic endowment insurance, this paper proposes the following countermeasures and suggestions: (1) broaden investment channels and improve the investment efficiency; (2) increase supervision of social security departments and strengthen information disclosure; (3) unify the management of social basic pension insurance.

Keywords: three-stage DEA, China's pension insurance, operating efficiency, technical efficiency

\section{Introduction}

Social basic pension insurance aims to protect the basic living needs of the elderly by means of social insurance and provide them with a stable and reliable source of life. It exerts an essential influence in the campaign of Chinese out of poverty, especially in the context of an aging population in China. With the continuous improvement of the basic pension insurance system reform and strengthening the social security system, China's basic pension insurance system has also been continuously developed, and its social security function has increased. ${ }^{1}$ The Chinese government announced new major plans at the Fifth Plenary Session of the Nineteenth Central Committee of the Communist Party of China. And the new goal of the Chinese government is to raise people's livelihood and welfare to a new level. Moreover, people's livelihood and well-being are regarded as one of the 
primary economic goals. In addition, the Chinese government has also proposed a major task of improving the multi-level social security system. Since the establishment of the Chinese pension system, it has always had a strong ability to pay, and there is a large amount of surplus every year.

In fact, China's basic pension insurance system was comprised of the basic pension insurance for urban and rural residents and urban employee's basic pension insurance, and the latter one had merged by the basic pension insurance for civil servants and public sector employees and the basic pension insurance for urban enterprise employees in 2015 officially. ${ }^{1}$ Despite they may work differently in target service groups and implementation intensity, they both work through the funds and realize their value preservation and appreciation. In China, the basic old-age insurance combine social pooling with individual accounts. And the basic pension insurance fund consists of employer and individual contributions and government subsidies. With the continuous development of fund service levels, its ability to pay and balances continue to increase. China's basic pension insurance fund has played a significant role in narrowing the gap between the rich and the poor, improved people's livelihood and enhanced welfare, and become one of the pillars of basic social insurance. However, there are big differences in the regional balances and payment ability of pensions in different regions. ${ }^{2}$ The practice in developed countries has proved to be very meaningful. For example, after becoming a generalized system of preferences, the pension system is an effective system guarantee for resolving the basic life risks of the elderly. However, it may also become an important source of social risks. ${ }^{3}$ So, in this context, we would like to seek and evaluate the operational efficiency of the basic pension fund in China, as a way to measure one of its management values, and how the main ingredients in its circumstances impact the operating efficiency. In summary, two questions this article seeks to answer are as follows:

Q1: What is the operating efficiency of China's basic pension insurance fund?

Q2: What is the impact of environmental variables on the operating efficiency of China's basic pension insurance fund?

In order to solve these problems, the Data Envelopment Analysis (DEA) was used to measure and evaluate the operating efficiency of China's basic pension insurance fund in 31 provinces in China from 2014 to
2019. The study hopes to conduct objective inspections and rational evaluations of the operating efficiency of China's basic pension insurance. Also, we analyzed the real dilemma in order to seek a new path for the development of a high-quality pension system.

This paper has the following three contributions. Firstly, although many scholars have conducted extensive researches on pension insurance, few studied China's basic pension insurance as a whole. And it is comprised of the basic pension insurance for urban and rural residents and the urban employee's basic pension insurance, let alone its operating efficiency. Secondly, the three-staged DEA model was considered as the first one to be used for the evaluation of China's basic pension insurance fund in our study. Thirdly, in addition to the measurement we do, several external environmental factors are also studied in this essay, which may explore the access to improve its efficiency. Therefore, this paper not only has theoretical reference value, but also produces certain administrative enlightenment and guiding significance for the actual decision-making process of government departments.

The remaining part of this paper is organized as follows. In Literature Review of this paper, we review the relevant literature on basic pension insurance funds at this stage. Materials and Methods discusses the methods and variables of the operation efficiency of China's basic pension insurance funds, and Analysis of Empirical Results makes an empirical analysis of the operation efficiency of China's pension insurance fund. In Conclusions and Suggestions, we give conclusions and suggestions on how to improve the operational efficiency of China's basic pension insurance in real life.

\section{Literature Review}

\section{The Income Redistribution Function of the Basic Pension Insurance}

Grignon et al (2020) pointed out that as a society, people should not only care about the efficiency of social security services but also how equitably they were distributed. ${ }^{4}$ The basic social pension insurance pays pensions based on the age of the insured. Differences in the insured income may lead to a reverse income redistribution effect of subsidizing the rich for the poor resulting in the unfair distribution of social resources. Zhou and Tan (2021) believe that the income gap between the elderly has declined slightly in recent years, and the contribution rate of pension has declined yearly. ${ }^{5}$ The reform of rural-urban residents' 
pensions has strengthened the ability of the entire social basic pension insurance system to adjust the income gap.

Judging from international experience, $\mathrm{Yu}, \mathrm{Li}$ and $\mathrm{Zhu}$ (2021) established a personal wage prediction model and an actuarial model of pension to calculate the present value of individual lifetime contributions, lifetime claims and lifetime real wages and incomes after pension adjustment under different overall planning levels. ${ }^{6}$ The results show that the basic endowment insurance for urban employees does have a significant income redistribution effect, and its income adjustment effect is positively related to the overall planning level and intensity of the system. The income redistribution effect of the system is the transfer of high-income groups to low-income groups, the transfer of the young generation to the elderly generation, the transfer of female insured persons to male insured persons, and the transfer of non-state-owned economic units to state-owned economic units.

\section{The Stability and Sustainability of Basic Pension Insurance Funds}

The stability of the basic pension insurance fund system interacts with economic growth fluctuations and demographic changes. In recent years, due to the gradual aging trend of the population and the fluctuation of economic growth, the stability and sustainability of the basic pension insurance fund system have received increasing attention from government officials, academic scholars, and individuals. ${ }^{7}$ For example, Sun, Nu and Xian (2020) simulated and predicted the short-term (2020-2025) and medium-term (2025-2050) effect of poverty alleviation policy on the sustainability of China's basic old-age insurance for urban and rural residents by establishing an actuarial model for the basic pension insurance for urban and rural residents in China. ${ }^{1}$ They found that under the current economic development and current policy conditions, with the decrease of the total population and the deepening of the aging of the population, the sustainability of the fund will inevitably encounter challenges.

In addition, Tian and Zhao (2016) used the Monte Carlo stochastic method to protect the dynamic process of the financial sustainability of the basic pension from 2013 to 2087 by 5000 times simulations. ${ }^{8}$ The prediction results indicate that the imbalance of the basic pension will occur in 2026. While Vukorepa (2015) proposed that in countries with high budget and pension system's deficits, unfavourable dependency ratios, long-term negative natural increase rates, low employment and high unemployment rates, the financial sustainability and adequacy of basic pension insurance will be lower. ${ }^{9}$

\section{Active Aging Research and Policies to Delay Retirement}

With social development, countries around the world are gradually facing the problem of aging population structure, and aging is seen as a challenge and threat to economic and social development. Polidano et al (2020) proposed that governments are responding to financial pressures related to an aging population and increasing the age of eligibility for publicly-funded retirement benefits. ${ }^{10}$ And Chen (2017) established a general analysis framework for the impact of the policies to delay retirement on China's basic pension income and expenditure, and found that policies of delaying retirement may not always have a positive and beneficial effect on alleviating the pension payment dilemma of pension payment. ${ }^{11}$ Additionally, Wang, Huang and Yang (2019) assessed the impact of recent reforms on the financial sustainability of China's Urban Employees' Pension Insurance (UEPP) and found that additional policy measures need to be designed to encourage childbirth and the postpone of retirement, including family support policies and carefully designed pension system reform policies. ${ }^{7}$

In summary, the existing research on the operating efficiency of basic pension insurance funds mainly focuses on the following three aspects: (1) the establishment of actuarial models to measure the income redistribution of basic pension insurance funds; (2) the establishment of predictive models to analyze the sustainability of China's basic pension insurance funds; (3) the evaluation of the effect of the active aging research and policies to delay retirement on basic pension insurance. However, there are still relatively few studies on measuring and evaluating the operating efficiency based on the microlevel. Among them, the revision and improvement of the three-stage DEA model is still an important research direction in the field of efficiency research. Therefore, this study quantitatively evaluates the operating efficiency of the basic pension insurance system, using the panel threestage DEA model to measure and assess the operating efficiency of China's basic pension insurance funds from 2014 to 2019 in 31 provinces in China. This paper timely grasps its operating status and discovers the existing problems, which have important practical significance for 
improving the operating capacity of the basic pension insurance system and promoting the sustainable development of the basic pension insurance system.

\section{Materials and Methods}

\section{The Construction of Three-Stage DEA}

Generally, there are several methods to measure the efficiency. Based on whether these methods are parametric or non-parametric, they are divided into two parts: (1) Stochastic Frontier Analysis (SFA), Distribution Free Analysis (DFA), Thick boundary Function Analysis (TFA) and Thick Recursive Frontier Analysis (TRFA); (2) Data Envelopment Analysis (DEA) and Free Disposal Hull (FDH).

Compared with other methods, DEA is suitable for multi-input and multi-output, and is widely used in practice. In 1978, A. Charnes ${ }^{12}$ first proposed the first DEA model CCR. DEA is a quantitative method often used to study complex systems' operating efficiency and evaluate the relative effectiveness of comparable units in the same type through linear programming, which is suitable for our research perfectly. SFA is a function of input, output and environmental factors, which is affected by random error and inefficiency. This method is widely used in practice because it can effectively distinguish inefficient items from error items. Still its limitation is that it can only measure the performance of single output. ${ }^{13}$ The three-stage DEA model is proposed by Fried et al (2002), which incorporates environmental factors and other random factors into the model. And the model which combines DEA with SFA can avoid the disadvantage that DEA is easily interfered by random error terms, and that's also why we use it in this paper.

This study used the information contained in the slack variable to adjust the input (or output) variables is mainly applied in this article to study the operating efficiency of China's basic pension insurance fund. ${ }^{12}$ The adjusted inputs (or outputs) of each decision-making unit overcome the shortcomings of the traditional DEA model, and filter the influence of external environmental effects and random factors on the efficiency evaluation, resulting in obtaining a more accurate and true efficiency status of the decisionmaking unit.

In the first stage of this model, the input-oriented BCC model is used to calculate the technical efficiency (TE), pure technical efficiency (PTE), and scale efficiency (SE) of each decision-making unit (DMU). TE is a comprehensive measurement and evaluation of the resource allocation ability and resource utilization efficiency of the DMU; PTE is the production efficiency due to factors such as management and technology, and the SE is the production efficiency due to the influence of scale factors. And there is a following relationship between them, that is, TE=PTE*SE. When the TE is equal to 1 , it means that the DMU is technically effective; when the TE is less than 1, it means that the DMU has not yet reached the production optimization. The BCC model can be expressed as:

$$
\begin{gathered}
\min \left[\theta-\varepsilon\left(e^{T} S^{-}+e^{T} S^{+}\right)\right]=T E \\
\sum_{i=1}^{n} X_{i} \lambda_{i}+S^{-}=\theta X_{i 0} \\
\sum_{i=1}^{n} Y_{i} \lambda_{i}-S^{+}=Y_{i 0}
\end{gathered}
$$

In order to further explore whether the overall operating inefficiency of the basic pension insurance is caused by pure technical inefficiency or scale inefficiency, we add a constraint condition to the CCR model and obtain the BCC model based on the assumption of variable scale return.

$$
\begin{gathered}
\min \left[\theta-\varepsilon\left(e^{T} S^{-}+e^{T} S^{+}\right)\right]=P T E \\
\sum_{i=1}^{n} X_{i} \lambda_{i}+S^{-}=\theta X_{i 0} \\
\sum_{i=1}^{n} Y_{i} \lambda_{i}-S^{+}=Y_{i 0} \\
\sum_{i=1}^{n} \lambda_{i}=1
\end{gathered}
$$

Where $\lambda_{i} \geqq 0, i=1,2,3, \ldots, \mathrm{n} ; S^{+} \geqq 0, S^{-} \geqq 0$; In equation (1) and (2), $\theta$ represents the effective value of the decisionmaking unit, $S^{+}, S^{-}$and $e$ represent input slack variables, residual variables and non-Archimedean infinitesimals, respectively. $X$ and $Y$ respectively represent the input and output combinations related to the operating efficiency of the basic pension insurance fund, and $\lambda_{i}$ represents the weight of the $i_{\text {th }}$ decision-making unit.

In the second stage, we use the SFA method to filter out the influence of environmental factors and managerial inefficiency, so that all decision-making units are in the same external environment, and the explained variables are the input redundancy in the first stage result, and the explanatory variables are the mixed error terms and 
environment variables. Therefore, the established SFA model is as follows:

$$
S_{n_{i}}=f\left(z_{i} ; \beta_{n}\right)+v_{n} ;+\mu_{n i} ; i=1,2, \cdots, I ; n=1,2, \cdots, N
$$

Where $S_{n i}$ represents the slack value of the $n$th input of the $i_{\text {th }}$ decision-making unit, and $Z_{i}$ represents the environmental variable. The coefficient of the environmental variable is $\beta_{n}$, the mixed error term is $V_{n i}+\mu_{n i}$, and the random interference is $V_{n i}$ and managerial inefficiency is $\mu_{n i}$. The random error term $V \sim N\left(0, \sigma_{v}^{2}\right)$ can be represented as the influence of random interference factors on the input slack variable. Managerial inefficiency $\mu$ is the influence of factors on the input slack variable, and it is assumed that $\mu \sim N^{+}\left(0, \sigma_{v}^{2}\right)$ is expressed as a normal distribution function truncated at zero.

In the third stage, the traditional DEA-BCC model is also adopted to measure the technical efficiency, pure technical efficiency and scale efficiency again. At this time, the efficiency has eliminated the influence of environmental factors and random interference, which is relatively real and accurate.

\section{Indicator Selection, Environment Variables and Data Source Input and Output Indicators}

In the analysis of the operating efficiency of China's basic pension insurance fund, the selection of input and output indicators is the key to evaluation, and different combinations of factors often produce certain differences in the output of the results. ${ }^{15}$ It will cause duplication of information and interference with each other if we select many indicators. Instead, it is a lack of sufficient representativeness that the selected indicators are not comprehensive enough. So the evaluation index system should be established on the basis of the principles of systemicity, consistency, independence, feasibility, and comparability. In addition, it is indispensable to fully consider the overlap between indicators to prevent the results from being biased and misleading as designing indicators. In order to ensure the accuracy of the calculation of the operating efficiency of China's basic pension insurance fund, we found through literature review that the input indicators mainly include income supplement, the growth rate of wage, and the number of people insured. Output indicators mainly include fund expenditure and accumulated fund balance. Based on previous research results and the actual situation of China's basic pension insurance fund, this paper finally selects fund income and the number of insured persons as input indicators, and fund expenditure and number of recipients as output indicators (see Table 1). ${ }^{16-24}$

\section{Environment Variables}

The selection of environmental variables based on the separation hypothesis is crucial to the three-stage DEA. They are supposed to have a certain degree of impact on the operating efficiency of China's basic pension insurance fund, but they cannot have a subjective control effect on the sample. Taking into account the characteristics of China's basic pension insurance fund and the research results of related scholars, this article takes the log of economic development level of each region (GDP), urbanization level, the dependency ratio of the elderly population, and the scale of government public expenditure as environmental variables that affect China's basic pension insurance fund.

Regional economic development level. The regional GDP growth rate is used to characterize the changes in the level of regional macroeconomic development. The operation of the basic pension insurance system is inseparable from government financial subsidies and support, and has a certain connection with the development of the regional macro-economy. At the same time, the study found that the level of regional economic development and the performance of government public service attacks also have a great relationship. ${ }^{2}$

The level of urbanization. The level of urbanization is the degree of urbanization in a region, usually expressed as the percentage of the city population and town population to the total population. ${ }^{25}$ On the one hand, urbanization is often accompanied by the agglomeration of capital and labor in various cities and towns. This clustering effect will promote local employment and economic development, promote residents' income levels. Additionally, it will provide better material conditions to local financial subsidies and individual contributions. For example, the level of urbanization has a very significant positive impact on the financial performance of the basic pension insurance for urban and rural residents. On the other hand, the level of urbanization is conducive to promoting the transformation of rural residents' subjective consciousness to citizens. It can also attract urban and rural residents to join the public service of basic pension insurance.

The old-age dependency ratio. We used the old-age dependency ratio to measure the impact of aging on the 
Table I Summary of Inputs and Outputs About Basic Pension Insurance

\begin{tabular}{|c|c|c|c|c|c|c|c|}
\hline \multicolumn{2}{|l|}{ Research } & \multicolumn{4}{|c|}{ Evaluated DMUs } & \multicolumn{2}{|c|}{ Inputs and Outputs } \\
\hline $\begin{array}{l}\text { Reference } \\
\text { Number }\end{array}$ & Author & Region & $\begin{array}{l}\text { Period } \\
\text { of } \\
\text { Study }\end{array}$ & $\begin{array}{l}\text { No. of } \\
\text { DMUs }\end{array}$ & Methods & Inputs & Outputs \\
\hline [16] & $\begin{array}{l}\text { Riumallo- } \\
\text { Herl et al } \\
(2019)\end{array}$ & Mexico & $\begin{array}{l}2008- \\
2012\end{array}$ & 2324 & $\begin{array}{l}\text { An Individual } \\
\text { Fixed- effects } \\
\text { Difference- in- } \\
\text { difference } \\
\text { Approach }\end{array}$ & Income, Supplement & $\begin{array}{l}\text { Healthcare use patterns, Out- } \\
\text { of- pocket, Expenditures and } \\
\text { Health Insurance Uptake } \\
\text { Patterns }\end{array}$ \\
\hline [17] & $\begin{array}{l}\text { Zavra et al } \\
(2002)\end{array}$ & USA & 1999 & 133 & $\begin{array}{c}\text { Dynamic } \\
\text { Network DEA }\end{array}$ & $\begin{array}{l}\text { Personnel, and the } \\
\text { Number of People } \\
\text { Covered by Each } \\
\text { Health Center }\end{array}$ & The Utilization of Services \\
\hline [18] & $\begin{array}{l}\text { Abruquah } \\
\text { et al (2019) }\end{array}$ & China & 2015 & 3815 & $\begin{array}{l}\text { Ordered Logit } \\
\text { Estimation }\end{array}$ & $\begin{array}{l}\text { Good Health, Personal } \\
\text { Financing, Wealth } \\
\text { Management }\end{array}$ & $\begin{array}{l}\text { The Life Satisfaction of } \\
\text { Retired Urban Residents }\end{array}$ \\
\hline [19] & $\begin{array}{l}\text { Oikonomou } \\
\text { et al (2015) }\end{array}$ & Greece & 2010 & 42 & $\begin{array}{l}\text { Restricted DEA } \\
\text { Model }\end{array}$ & $\begin{array}{l}\text { Medical Personnel, } \\
\text { Nursing Personnel and } \\
\text { Technological } \\
\text { Equipment }\end{array}$ & $\begin{array}{c}\text { Acute, Chronic and } \\
\text { Preventive Consultations }\end{array}$ \\
\hline [20] & Yang (20I8) & China & 2015 & 31 & SBM-DEA Model & $\begin{array}{l}\text { Number of Insured, } \\
\text { Basic Pension Fund } \\
\text { Income, Number of } \\
\text { Retirees }\end{array}$ & $\begin{array}{c}\text { Basic Pension Fund } \\
\text { Expenditure, Accumulated } \\
\text { Balance of Basic Pension Fund }\end{array}$ \\
\hline [2I] & $\begin{array}{l}\text { Han and } \\
\text { Meng (202I) }\end{array}$ & China & 2011 & 31 & Data Analysis & $\begin{array}{c}\text { Average Wage Level, } \\
\text { Aging Population, Fiscal } \\
\text { Revenue as } \\
\text { a Percentage of GDP }\end{array}$ & Fund's Revenue \\
\hline [22] & $\begin{array}{l}\text { Khushalani } \\
\text { and Ozcan } \\
\qquad(2017)\end{array}$ & USA & $\begin{array}{c}2009- \\
2013\end{array}$ & 1259 & $\begin{array}{c}\text { Dynamic } \\
\text { Network DEA }\end{array}$ & $\begin{array}{c}\text { Number of Beds, Total } \\
\text { Number of Non- } \\
\text { physician FTEs }\end{array}$ & $\begin{array}{l}\text { Total Number of Surgeries, } \\
\text { Emergency Visits and } \\
\text { Outpatient Visits }\end{array}$ \\
\hline [23] & $\begin{array}{l}\text { Sultan and } \\
\text { Crispim } \\
(2018)\end{array}$ & Palestini-an & $\begin{array}{c}2010 \\
2015\end{array}$ & 11 & Two-stage DEA & $\begin{array}{l}\text { Full-time employees, } \\
\text { The Number of } \\
\text { Hospital Beds, Other } \\
\text { Resources }\end{array}$ & $\begin{array}{l}\text { Total Number of Annual Care } \\
\text { Days, Total Number of Annual } \\
\text { Visits, Total Annual Number } \\
\text { of Cases }\end{array}$ \\
\hline [24] & $\begin{array}{l}\text { Flokou et al } \\
\qquad(2017)\end{array}$ & Greece & $\begin{array}{l}2009- \\
2013\end{array}$ & 107 & Window-DEA & $\begin{array}{l}\text { Total Hospital Beds, } \\
\text { Full Time Equivalent } \\
\text { Physicians, Other Staff }\end{array}$ & $\begin{array}{c}\text { Inpatient Cases, Operations, } \\
\text { Outpatient Visits }\end{array}$ \\
\hline
\end{tabular}

Abbreviations: DMUs, decision making units; DEA, data envelopment analysis.

operating efficiency of the basic pension insurance fund. The demographic structure will have a certain impact on the operating efficiency of the basic pension insurance system. ${ }^{26}$ As China's aging degree continues to rise, meeting the public's needs is the starting point and end point for the government to provide public services. The public's social security needs are closely related to various demographic factors. And the scale effect formed by population agglomeration is conducive to reducing the regulatory cost of public services provided by the government in the region, it may affect the operating efficiency of China's pension insurance fund to a certain extent. ${ }^{8}$ 
The scale of government public expenditure. The level of regional public financial expenditure is measured by the ratio of local public financial expenditure to regional GDP. Financial subsidy income has always been the main component of the basic pension insurance fund income, which will affect the scale and efficiency of rural social security fiscal expenditures in various regions to a certain extent. ${ }^{1}$ So changes in the level of local public financial expenditures are also related to the total amount of basic pension insurance funds.

\section{Data Source}

This paper studies the operating efficiency of basic pension insurance funds in 31 provinces in China from 2014 to 2019. The data of input, output indicators and environmental variables are derived from this year's "China Statistical Yearbook" and statistical yearbooks of various provinces (see Table 2). In order to further analyze the differences in the operating efficiency of basic pension insurance funds in various regions of China, this paper divides China's 31 provincial administrative units into Eastern, Central and Western regions.

\section{Analysis of Empirical Results Correlation Analysis}

It is necessary to perform a correlation test on the inputs and outputs to determine whether the two influence each other, as we use the three-stage DEA model to analyze. From the results of the estimated correlation coefficients, the correlations between all input indicators and output indicators are greater than 0.66 . They are significantly correlated at the 0.01 significance level, indicating that inputs and outputs
Table 3 Correlation Analysis of Inputs and Outputs

\begin{tabular}{|l|c|c|c|c|}
\hline & $\begin{array}{c}\text { Fund } \\
\text { Expenditure }\end{array}$ & $\begin{array}{c}\text { Number of } \\
\text { Recipients }\end{array}$ & $\begin{array}{c}\text { Fund } \\
\text { Income }\end{array}$ & $\begin{array}{c}\text { Insured } \\
\text { Persons }\end{array}$ \\
\hline Fund Expenditure & 1 & & & \\
\hline $\begin{array}{l}\text { Number of } \\
\text { Recipients }\end{array}$ & $0.756^{* * *}$ & 1 & & \\
\hline Fund Income & $0.889^{* * *}$ & $0.682^{* * * *}$ & 1 & \\
\hline Insured Persons & $0.668^{* * *}$ & $0.941^{* * *}$ & $0.682^{* * *}$ & 1 \\
\hline
\end{tabular}

Note: $* * *$ Indicates significant $p$ values at the $1 \%$.

have a high correlation, which meets the DEA model's requirements for data equivariance. The Pearson correlation matrix of input-output data indicators is shown in Table 3.

\section{Results of the DEA Model at Stage I}

The DEAP 2.1 was used to analyze the original inputs and outputs, assuming that the return to scale is variable. Moreover, the input-oriented BCC model was used to measure the technical efficiency, scale efficiency and pure technical efficiency of the basic pension insurance funds in 31 provinces from 2014 to 2019. Overall, China's basic pension insurance fund has a good operating efficiency during the sample years. The average values of TE, PTE and SE are $0.855,0.910$ and 0.941 , respectively. There is still a lot of room for improvement. As shown in Table 4, in all provinces, Jilin and Shanghai have maintained a technical efficiency of 1.000 in 6 years; that is, they are at the forefront of technical efficiency and are efficient. Other provinces have room for improvement in terms of PTE and SE. From a regional perspective, the

Table 2 Descriptive Analysis of Inputs, Outputs and Environmental Variables

\begin{tabular}{|c|c|c|c|c|c|c|}
\hline & Variables & Mean & $\begin{array}{l}\text { Standard } \\
\text { Deviation }\end{array}$ & Minimum & Median & Maximum \\
\hline \multirow[t]{2}{*}{ Inputs } & Fund Income (I00 Million RMB) & 1377.02 & 1018.11 & 29.20 & 1117.80 & 5877.50 \\
\hline & $\begin{array}{l}\text { Number of Insured persons (10 Thousand } \\
\text { People) }\end{array}$ & 2909.51 & 2003.09 & 156.10 & 2454.35 & 7935.60 \\
\hline \multirow[t]{2}{*}{ Outputs } & Fund Expenditure (100 Million RMB) & 860.10 & 18.40 & 1014.05 & 4011.60 & 860.10 \\
\hline & Number of Recipients (10 Thousand People) & 564.67 & 13.20 & 678.55 & 2243.80 & 564.67 \\
\hline \multirow{4}{*}{$\begin{array}{l}\text { Environmental } \\
\text { Variables }\end{array}$} & Log (GDP) (I00 Million RMB) & 4.27 & 0.42 & 2.96 & 4.31 & 5.03 \\
\hline & Urbanization Level (\%) & 58.31 & 12.36 & 25.75 & 56.79 & 89.60 \\
\hline & Dependency Ratio of the Elderly Population (\%) & 14.74 & 3.43 & 7.01 & $|4.4|$ & 23.82 \\
\hline & Scale of Government Public Expenditure (\%) & 29.03 & 21.38 & 11.98 & 23.83 & 137.92 \\
\hline
\end{tabular}


Table 4 Technical Efficiency of China's Basic Pension Insurance from 2014 to 2019

\begin{tabular}{|c|c|c|c|c|c|c|c|c|}
\hline Region & Province & 2014 & 2015 & 2016 & 2017 & 2018 & 2019 & Mean \\
\hline \multirow{12}{*}{ Eastern China } & Beijing & 0.669 & 0.616 & 0.734 & 0.635 & 0.617 & 0.575 & $0.64 I$ \\
\hline & Tianjin & I & 1 & I & 0.988 & 0.995 & 0.957 & 0.99 \\
\hline & Hebei & 0.945 & 0.991 & 0.944 & 0.977 & 0.941 & 0.902 & 0.95 \\
\hline & Shanxi & 0.936 & 0.963 & 0.982 & 0.994 & I & 1 & 0.979 \\
\hline & Shanghai & 1 & I & I & I & 1 & 1 & 1 \\
\hline & Jiangsu & 0.868 & 0.904 & 0.881 & 0.893 & 0.896 & 0.876 & 0.886 \\
\hline & Zhejiang & 0.728 & 0.789 & 0.842 & 0.856 & 0.838 & 0.821 & 0.812 \\
\hline & Fujian & 0.81 & 0.818 & 0.784 & 0.831 & 0.876 & 0.629 & 0.791 \\
\hline & Shandong & 0.852 & 0.828 & 0.859 & 0.95 & 0.979 & I & 0.911 \\
\hline & Guangdong & 0.585 & 0.527 & 0.508 & 0.526 & 0.541 & 0.536 & 0.537 \\
\hline & Hainan & 0.888 & 0.809 & 0.74 & 0.718 & 0.729 & 0.634 & 0.753 \\
\hline & Mean & 0.844 & 0.840 & 0.843 & 0.852 & 0.856 & 0.812 & 0.841 \\
\hline \multirow[t]{9}{*}{ Central China } & Shanxi & 0.77 & 0.846 & 0.791 & 0.745 & 0.854 & 0.693 & 0.783 \\
\hline & Jilin & 1 & 1 & I & I & I & I & I \\
\hline & Heilongjiang & 1 & I & I & I & I & 0.983 & 0.997 \\
\hline & Anhui & 0.904 & 0.945 & 0.984 & I & 0.861 & 0.677 & 0.895 \\
\hline & Jiangxi & 0.884 & $0.87 \mid$ & 0.895 & 0.863 & 0.902 & 0.728 & 0.857 \\
\hline & Henan & 0.961 & 1 & 1 & 1 & 1 & 0.653 & 0.936 \\
\hline & Hubei & 0.912 & 0.917 & 0.945 & 0.909 & 0.98 & 0.811 & 0.912 \\
\hline & Hunan & 0.921 & 0.951 & 0.957 & 0.963 & 0.887 & 0.684 & 0.894 \\
\hline & Mean & 0.919 & 0.941 & 0.947 & 0.935 & 0.936 & 0.779 & 0.909 \\
\hline \multirow[t]{13}{*}{ Western China } & Inner Monglia & 0.883 & 0.874 & 0.862 & 0.843 & 0.87 & 0.869 & 0.867 \\
\hline & Guangxi & I & 1 & 0.933 & 0.941 & 0.952 & 0.752 & 0.93 \\
\hline & Chongqing & 0.949 & 0.944 & 0.958 & 0.892 & 0.971 & 0.726 & 0.907 \\
\hline & Sichuan & I & I & 0.942 & 0.921 & I & 0.839 & 0.95 \\
\hline & Guizhou & I & I & 1 & 0.872 & 0.876 & 0.663 & 0.902 \\
\hline & Yunnan & 0.857 & 0.9 & 0.803 & 0.759 & 0.876 & 0.61 & 0.801 \\
\hline & Tibet & 0.642 & 0.676 & 0.491 & 0.515 & 0.729 & 0.433 & 0.581 \\
\hline & Shannxi & 0.87 & 0.924 & 0.869 & 0.83 & 0.884 & 0.685 & 0.844 \\
\hline & Gansu & 0.837 & 0.95 & 0.928 & 0.972 & 0.945 & 0.645 & 0.88 \\
\hline & Qinghai & 0.855 & 0.878 & 0.791 & 0.83 & 0.86 & 0.606 & 0.803 \\
\hline & Ningxia & 0.886 & 0.794 & 0.698 & 0.751 & 0.765 & 0.642 & 0.756 \\
\hline & Xinjiang & 0.738 & 0.705 & 0.868 & 0.804 & 0.759 & 0.591 & 0.744 \\
\hline & Mean & 0.876 & 0.887 & 0.845 & 0.828 & 0.874 & 0.672 & 0.830 \\
\hline \multicolumn{2}{|c|}{ Mean of all provinces } & 0.876 & 0.885 & 0.87 I & 0.864 & 0.883 & 0.749 & 0.855 \\
\hline
\end{tabular}

average technical efficiency of China's Eastern, Central and Western are 0.841, 0.909 and 0.830, respectively, showing a situation of Central $>$ Eastern $>$ Western, and the average technical efficiency of Eastern and Western regions has not reached the national average.

Table 4 shows the technical efficiency of China's basic pension insurance fund from 2014 to 2019 without considering the impact of environmental factors and random factors, and does not truly reflect the actual situation. Due to the objective differences in the level of economic and social development in various regions, the external environment faced by the basic pension insurance funds in various regions is also quite different. The efficiency value measured in the first stage includes the impact of external environmental variables and random errors on the efficiency value. Therefore, it is necessary to re-measure and evaluate the operating efficiency of China's basic pension insurance fund after excluding the influence of environmental factors and random interference factors.

\section{Results of the SFA Model at Stage 2}

At stage 2, the explained variables are the redundant inputs inferred from the traditional DEA model at stage 1, and the explanatory variables are four environmental indicators. Through the Frontier 4.1, the influence of environmental 
Table 5 Results of the SFA Model at Stage 2

\begin{tabular}{|l|c|c|}
\hline Variables & $\begin{array}{c}\text { Slack of } \\
\text { Fund } \\
\text { Income }\end{array}$ & $\begin{array}{c}\text { Slack of the Number } \\
\text { of Insured Persons }\end{array}$ \\
\hline Constant & $3151.8902 * * *$ & $5502.6009 * * *$ \\
Log (GDP) & $-722.98018^{* * *}$ & $-1663.3359 * * *$ \\
Urbanization Level & $-1101.1538^{* * *}$ & -985.28031 \\
Dependency Ratio & $2770.4783^{* * *}$ & $10,917.413^{* * *}$ \\
Scale of Government & $-\left.795.4087\right|^{* * *}$ & $-950.33456^{* * *}$ \\
Public Expenditure & $118,417.81^{* * *}$ & $31,995.433^{* * *}$ \\
$\sigma 2$ & $0.52499513^{* * * *}$ & $12.764522^{* * *}$ \\
$\gamma$ & $-1305.1259 * * *$ & $-1397.4159 * * *$ \\
Log likelihood & $29.303176 * * *$ & $42.308465^{* * *}$ \\
\hline Likelihood Ratio &
\end{tabular}

Note: $* * *$ Indicates significant $p$ values at the $1 \%$.

variables is estimated using the maximum likelihood estimation (MLE). The regression analysis results of the SFA model (as shown in Table 5) show that the four environmental indicators pass the $1 \%$ level of significance test, which shows the rationality of the environmental indicators selected in this paper. As a result, in order to further adjust the input variables, it is crucial to eliminate the influence of environmental factors on the redundancy of input variables through SFA analysis.

\section{The Log of Each Region's Economic Development Level GDP}

The regression results show that the regression coefficients of the $\log$ of GDP, redundancy of fund income and the redundancy of the number of insured are all negative, and they have passed the $1 \%$ significance test. It indicates that the increase in fund income and the number of insured is conducive to the rapid development of China's pension insurance, that is, the regional macroeconomic development level is beneficial to promoting the efficiency of China's pension insurance fund operation.

\section{The Level of Urbanization}

The urbanization level had a negative relationship with the slack variables of fund income and the slack variables of the number of insured.The convergence of production factors caused by urbanization can not only promote the rapid development of the regional economy, but also eases the pressure of local finance to subsidize pension insurance. In addition, people's demand for this typical public service is even stronger. And the transformation increases the coverage of basic pension insurance, which is conducive to promoting the efficiency of the basic pension insurance system.

\section{The Old-Age Dependency Ratio}

This variable has a positive relationship with the slack variable of fund income and the number of insured. And both relationships have passed the significance test of $1 \%$. The results show that the old-age dependency ratio is not conducive to promoting the efficiency of the basic pension insurance fund. The reason may be due to the increase in the old-age dependency ratio and the increased pressure on the operation of the fund. However, However, the management level and scale efficiency of the fund have not been significantly improved, which has exacerbated the phenomenon of fund investment redundancy. Therefore, the larger the dependency ratio of the elderly population, the less conducive to the improvement of the efficiency of fund utilization.

\section{The Scale of Government Public Expenditure}

The scale of government public expenditure had negative relationship with the slack variable of fund income and the slack variable of the number of insured at the $1 \%$ level of significance.This means that the level of government public expenditure is conducive to promoting the efficiency of the basic pension insurance system. This is because government public expenditures are mainly used for subsidies in basic pension insurance, and the increase in government expenditure levels is conducive to residents' participation in insurance, increasing the subsidy of the basic pension insurance fund, thereby improving the operating efficiency of the basic pension insurance fund.

\section{Results of the DEA Model at Stage 3}

We use DEAP 2.1 to analyze the adjusted input-output data using the BCC-DEA model, and obtain the true efficiency of the basic pension insurance fund in 31 provinces of China. On the basis of the adjusted input variable values obtained in the second stage, we replace the raw input value at stage 1 and again use the input-oriented BCC model to measure efficiency under the unified frontier, and obtain the operating efficiency of basic pension insurance fund for each province at stage 3 . It can be seen from Table 6 that after removing the influence of environmental factors and random interference, it is found that there is a certain deviation in the measurement results of the two stages, which indicates that it is meaningful to construct the SFA model for estimation at stage 2. 
Table 6 Results of Stage I and Stage 3

\begin{tabular}{|c|c|c|c|c|c|c|c|c|c|}
\hline \multicolumn{2}{|l|}{ Region } & \multicolumn{4}{|c|}{ Results of Stage I } & \multicolumn{4}{|c|}{ Results of Stage 3} \\
\hline & & \multirow{2}{*}{$\begin{array}{c}\text { TE } \\
0.64 I\end{array}$} & \multirow{2}{*}{$\begin{array}{l}\text { PTE } \\
0.651\end{array}$} & \multirow{2}{*}{$\begin{array}{c}\text { SE } \\
0.983\end{array}$} & \multirow{2}{*}{$\begin{array}{l}\text { RS } \\
\text { irs }\end{array}$} & \multirow{2}{*}{$\begin{array}{c}\text { TE } \\
0.464\end{array}$} & \multirow{2}{*}{$\begin{array}{l}\text { PTE } \\
0.582\end{array}$} & \multirow{2}{*}{$\begin{array}{c}\text { SE } \\
0.793\end{array}$} & \multirow{2}{*}{$\begin{array}{l}\text { RS } \\
\text { irs }\end{array}$} \\
\hline Eastern China & Beijing & & & & & & & & \\
\hline & Tianjin & 0.990 & 1.000 & 0.990 & irs & 0.515 & 0.766 & 0.656 & irs \\
\hline & Hebei & 0.950 & 0.966 & 0.983 & irs & 0.914 & 0.958 & 0.954 & irs \\
\hline & Liaoning & 0.979 & 1.000 & 0.979 & - & 1.000 & 1.000 & 1.000 & - \\
\hline & Shanghai & 1.000 & 1.000 & 1.000 & - & 0.843 & 0.879 & 0.962 & irs \\
\hline & Jiangsu & 0.886 & 0.996 & 0.890 & drs & 0.858 & 0.981 & 0.877 & drs \\
\hline & Zhejiang & 0.812 & 0.898 & 0.907 & drs & 0.747 & 0.812 & 0.918 & drs \\
\hline & Fujian & 0.791 & 0.804 & 0.985 & irs & 0.498 & 0.756 & 0.648 & irs \\
\hline & Shandong & 0.911 & 1.000 & 0.911 & - & 0.984 & 1.000 & 0.984 & - \\
\hline & Guangdong & 0.537 & 0.649 & 0.865 & drs & 0.486 & 0.591 & 0.892 & drs \\
\hline & Hainan & 0.753 & 0.895 & 0.841 & irs & 0.270 & 0.954 & 0.283 & irs \\
\hline & Mean & 0.841 & 0.896 & 0.939 & & 0.689 & 0.843 & 0.815 & \\
\hline \multirow[t]{9}{*}{ Central China } & Shanxi & 0.783 & 0.791 & 0.990 & irs & 0.563 & 0.753 & 0.734 & irs \\
\hline & Jilin & 1.000 & 1.000 & 1.000 & - & 0.614 & 0.880 & 0.688 & irs \\
\hline & Heilongjiang & 0.997 & 0.999 & 0.998 & irs & 0.897 & 0.973 & 0.919 & irs \\
\hline & Anhui & 0.895 & 0.908 & 0.985 & drs & 0.738 & 0.854 & 0.852 & irs \\
\hline & Jiangxi & 0.857 & 0.867 & 0.988 & irs & 0.620 & 0.848 & 0.727 & irs \\
\hline & Henan & 0.936 & 0.962 & 0.968 & drs & 0.908 & 0.913 & 0.990 & irs \\
\hline & Hubei & 0.912 & 0.939 & 0.971 & drs & 0.810 & 0.862 & 0.935 & irs \\
\hline & Hunan & 0.894 & 0.926 & 0.966 & drs & 0.789 & 0.877 & 0.894 & irs \\
\hline & Mean & 0.909 & 0.924 & 0.983 & & 0.742 & 0.870 & 0.842 & \\
\hline \multirow[t]{13}{*}{ Western China } & Inner Monglia & 0.867 & 0.890 & 0.975 & irs & 0.551 & 0.814 & 0.672 & irs \\
\hline & Guangxi & 0.930 & 0.939 & 0.990 & irs & 0.675 & 0.895 & 0.749 & irs \\
\hline & Chongqing & 0.907 & 0.918 & 0.988 & irs & 0.646 & 0.900 & 0.711 & irs \\
\hline & Sichuan & 0.950 & 0.997 & 0.953 & drs & 0.905 & 0.911 & 0.991 & irs \\
\hline & Guizhou & 0.902 & 0.921 & 0.977 & irs & 0.558 & 0.926 & 0.600 & irs \\
\hline & Yunnan & 0.801 & 0.817 & 0.979 & irs & 0.543 & 0.819 & 0.661 & irs \\
\hline & Tibet & $0.58 \mathrm{I}$ & 1.000 & 0.581 & irs & 0.085 & 1.000 & 0.085 & irs \\
\hline & Shannxi & 0.844 & 0.851 & 0.991 & irs & 0.618 & 0.826 & 0.742 & irs \\
\hline & Gansu & 0.880 & 0.918 & 0.956 & irs & 0.494 & 0.949 & 0.516 & irs \\
\hline & Qinghai & 0.803 & 0.970 & 0.826 & irs & 0.240 & 0.991 & 0.242 & irs \\
\hline & Ningxia & 0.756 & 0.958 & 0.789 & irs & 0.250 & 0.994 & 0.252 & irs \\
\hline & Xinjiang & 0.744 & 0.774 & 0.959 & irs & 0.500 & 0.756 & 0.655 & irs \\
\hline & Mean & 0.830 & 0.913 & 0.914 & & 0.505 & 0.898 & 0.573 & \\
\hline \multicolumn{2}{|c|}{ Mean of all Provinces } & 0.855 & 0.910 & 0.941 & & 0.632 & 0.872 & 0.728 & \\
\hline
\end{tabular}

Abbreviations: TE, technical efficiency; PTE, pure technical efficiency; SE, scale efficiency; RS, return to scale.

Technical Efficiency of Basic Pension Insurance Funds After excluding the external environment and random influencing factors, the average comprehensive technical efficiency of basic old-age insurance funds in various provinces and cities decreased from 0.855 to 0.632 , with a decrease of $26.082 \%$. From Figure 1, it can be seen that only Liaoning and Shandong provinces have increased overall efficiency, while the overall efficiency of the remaining regions has decreased to varying degrees in the third stage. Among them, the four provinces of Hainan, Tibet, Qinghai and Ningxia have adjusted their overall efficiency. The efficiency value is very low, respectively $0.270,0.085,0.240$ and 0.250 , especially in Tibet, only 0.085 , a drop of $85.370 \%$; while Liaoning increased from 0.979 to 1 , which is the only province at the frontier of efficiency among 31 provinces, indicating that the operation efficiency of basic pension insurance fund in Liaoning province is very stable. This also shows that 


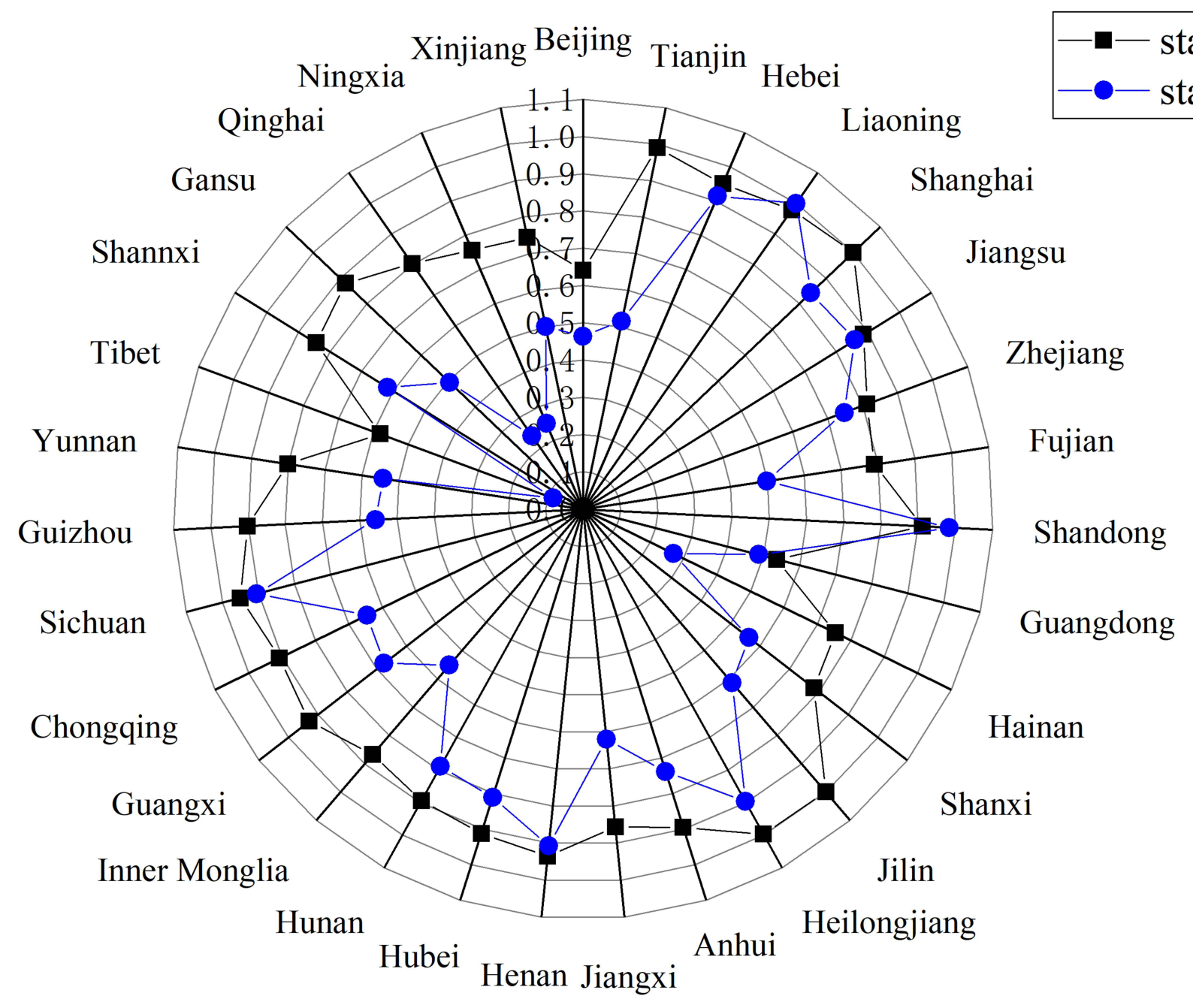

Figure I Radar chart of technical efficiency.

there are great differences in the operational efficiency of basic pension insurance funds in different regions of China. The efficiency levels of Jilin and Shanghai provinces have declined and are no longer at the forefront of efficiency, indicating that the efficiency values of the first stage of these two regions may be related to their external environment and business luck, and cannot reflect their true management levels. Since TE=PTE*SE, we will continue to analyze the two parts of pure technical efficiency and scale efficiency.

\section{Pure Technical Efficiency of Basic Pension Insurance Funds}

As shown in Figure 2, compared with the comprehensive technical efficiency, the number of provinces with pure technical efficiency has increased significantly. Before the index adjustment, Tianjin, Liaoning, Shanghai, Shandong, Jilin and Tibet achieved technical efficiency. After the adjustment, only Liaoning, Shandong and Tibet achieved pure technical efficiency and the rest were technically ineffective. This shows that the basic endowment insurance funds in Liaoning, Shandong and Tibet are at the current technical level. The use of its input resources is efficient. The fundamental reason why Shandong and Tibet fail to achieve comprehensive efficiency is that their scale is ineffective. Therefore, the focus of its reform lies in how to give full play to its scale benefits. In addition, after adjustment, there are six provinces and cities with improved pure technical efficiency, namely Hainan, Guizhou, Yunnan, Gansu, Qinghai and Ningxia. It is noted that except Yunnan, the pure technical 


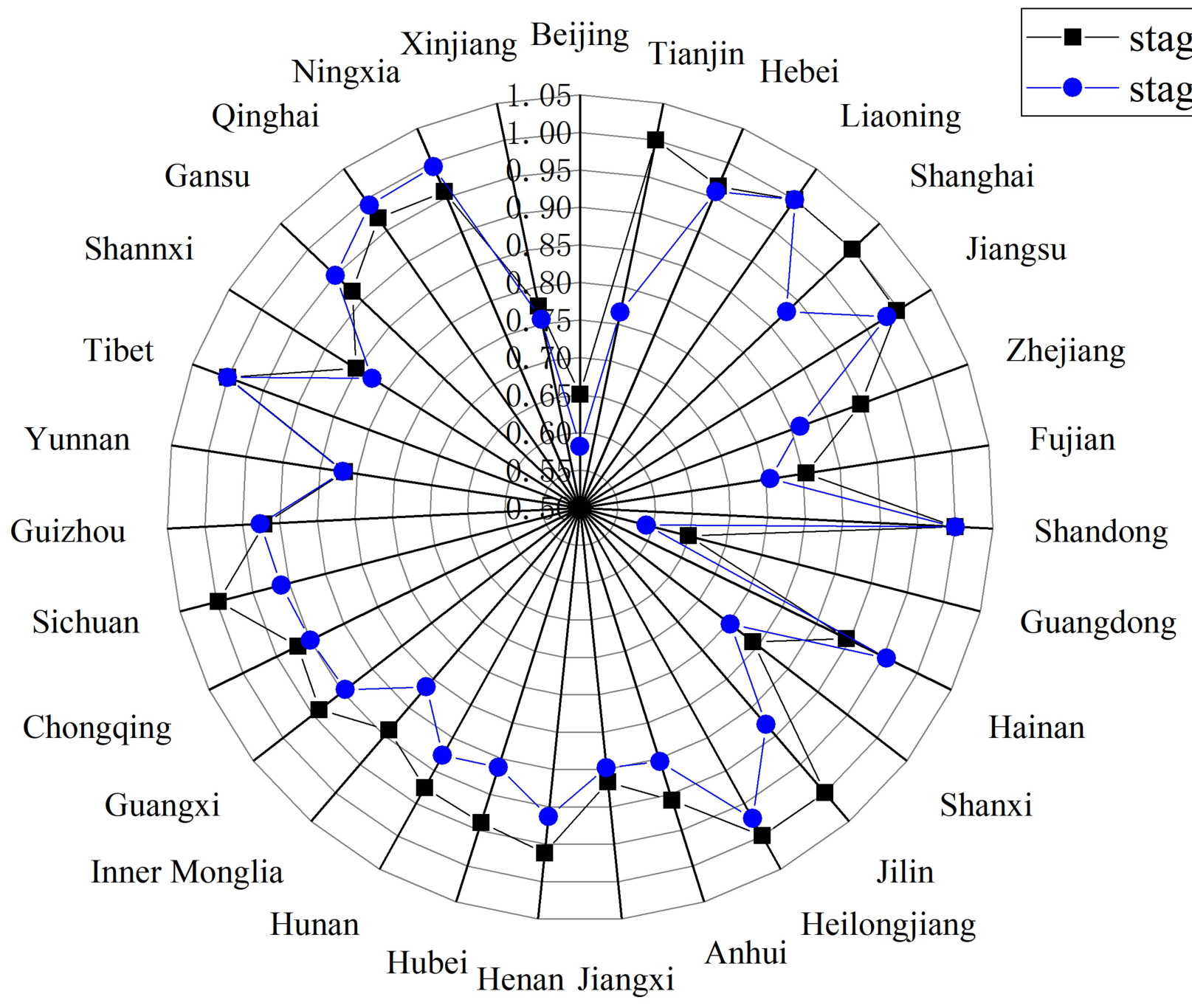

Figure 2 Radar chart of pure technical efficiency.

efficiency is 0.819 , and the efficiency values of the other five regions are all above 0.900 , which shows that the management and technical level of basic old-age insurance funds in these regions are better and have certain advantages.

\section{Scale Efficiency of Basic Pension Insurance Funds}

After excluding the external environment and random influencing factors, the average scale efficiency of 31 provinces' basic pension insurance funds decreased from 0.941 before adjustment to 0.728 after adjustment. The changes in scale efficiency of various provinces are shown in Figure 3. Before the indicator adjustment, Shanghai and Jilin reached technical efficiency. After the indicator adjustment, the two regions became technically ineffective. Instead, Liaoning became the only province in the country that achieved scale efficiency and technically effective. In addition, in addition to Liaoning, the scale efficiency of five provinces and cities has increased, namely Zhejiang, Shanghai, Guangdong, Henan and Sichuan, and the efficiency values are all at a relatively high level, indicating that their fund scales are more reasonable. The gap in the optimal scale of operation is not large. However, in sharp contrast, the four provinces of Hainan, Tibet, Qinghai, and Ningxia had extremely low SE in the third stage, which eventually led to them becoming the four regions with the lowest overall efficiency of the basic pension insurance fund in the country, even if they perform well in pure technical efficiency, and they cannot make up for their shortcomings in scale efficiency. The reason is that their economic development is relatively backward, resulting in insufficient scale and 


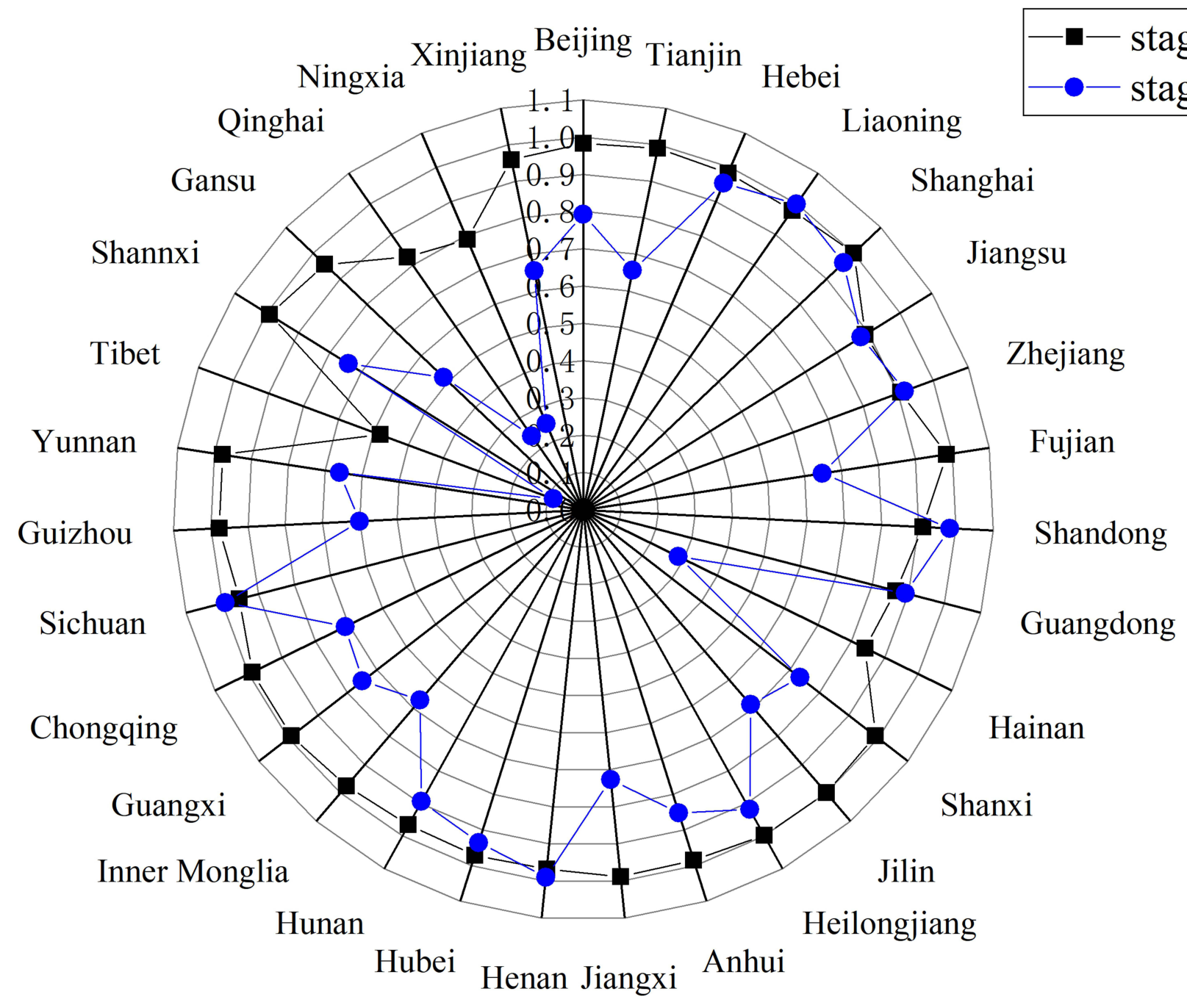

Figure 3 Radar chart of scale efficiency.

low scale efficiency of the basic pension insurance fund Therefore, these areas should pay attention to the reasonable allocation of resources and improve the efficiency of use.

\section{Regional Distribution of Technical Efficiency in China's Basic Pension Insurance Funds}

Based on China's economic development level and geographic location, combined with long-term evolution, we can divide China as a whole into three major economic regions, namely the Central, the Eastern and the Western.

From a regional perspective, the average comprehensive technical efficiency of the Eastern, Central, and Western at stage 3 are $0.689,0.742$ and 0.505 respectively, which are consistent with the conclusions from stage 1, and still present a pattern of Central> Eastern $>$ Western. As shown in Figure 4, the average decline in TE in the Western region was the most obvious, followed by the Central region. The reason is that the higher pure technical efficiency and scale efficiency of the Central region ensure the leading comprehensive technical efficiency, which matches the economic strength and financial resources of the Central region. The operating efficiency of the basic pension insurance system in the Central region is better than that in the Eastern region. The possible explanation is that compared with the Eastern region, the Central region has received more central fiscal transfer payments in terms of social security and people's livelihood in recent years. In addition, in terms of subsidies for basic pension insurance, compared with the Eastern region, the Central region has a higher subsidy standard for individual contribution, which is more attractive to the 


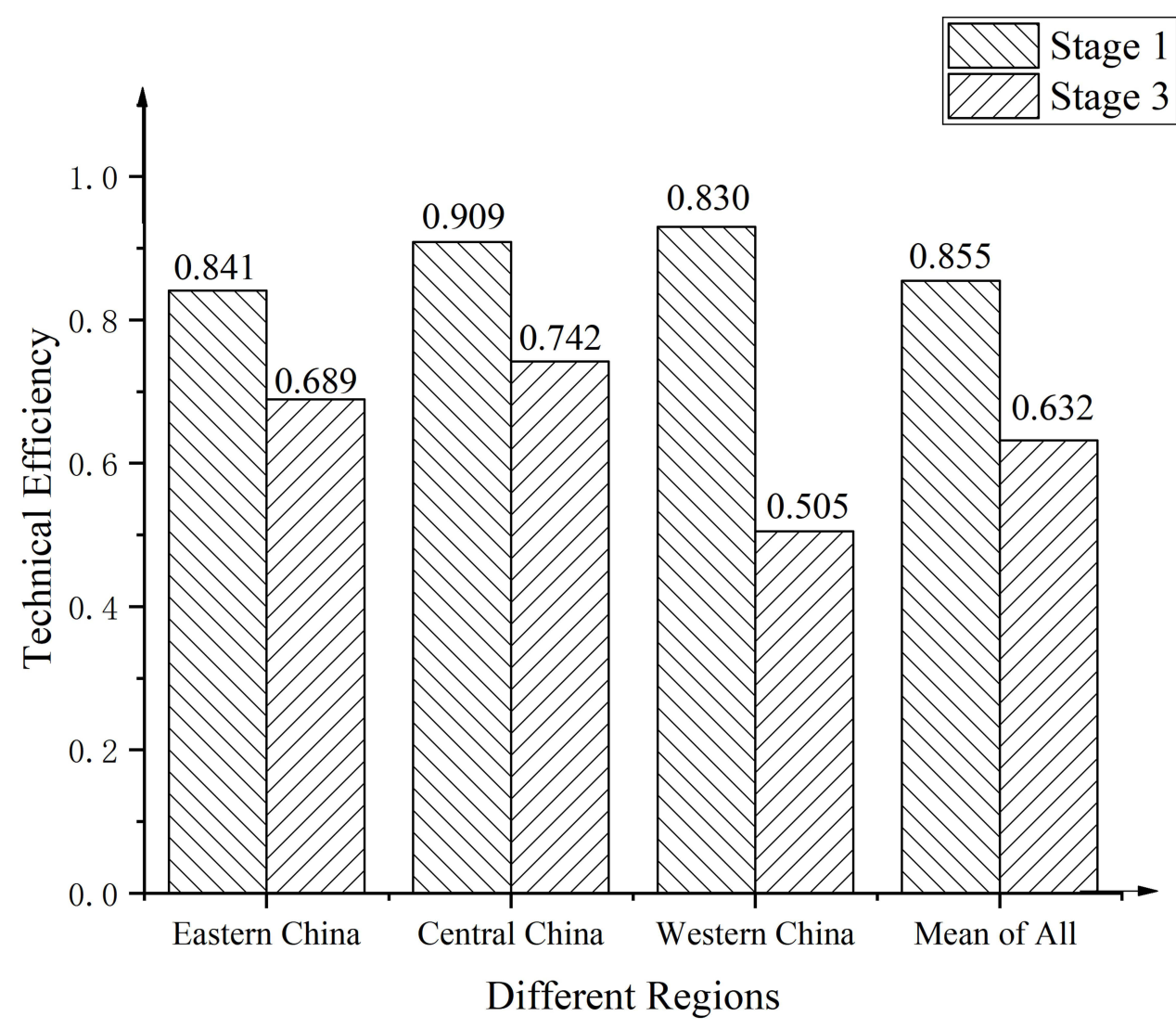

Figure 4 Technical efficiency distribution in different regions.

insured objects. The efficiency value calculation results of the two stages both show that lower scale efficiency is the key to restricting the efficiency improvement in the Eastern region, indicating that the investment in the basic pension insurance system in the Eastern region has not yet reached the optimal scale, and further measures need to be taken to achieve the goal of assuring all those should be assured, such as strengthening policy publicity and increasing fund income. From the national average pure technical efficiency, from 0.910 at stage 1 to 0.872 at stage 3, the drop was $4.18 \%$. From the perspective of the average pure technical efficiency of the region, the average PTE of the Eastern, Central, and Western at stage 3 are 0.843, 0.87, and 0.898, respectively, and the Eastern and Central are both lower than the national average. From the perspective of scale efficiency, the average SE of the Eastern, Central, and Western at stage 3 are $0.815,0.842$, and 0.573 respectively. Only the Western region is lower than the national average. Lower scale efficiency is still the main reason restricting the efficiency improvement of the Western region.

\section{Conclusions and Suggestions}

The three-stage DEA model is used to analyze China's basic pension insurance fund. This study used fund income and number of participants as input indicators, fund expenditure and number of recipients as output indicators, and calculated the operational efficiency, pure technical efficiency, and scale efficiency of China's 31 provinces from 2014 to 2019. On the whole, the operating efficiency of China's basic pension insurance is at a relatively low level, but there is still a lot of room for efficiency improvement.

Comparing the efficiency of the first stage, environmental factors and random interference have a significant impact on the operating efficiency of the basic pension insurance. After excluding the influence of environmental factors, the average values of technical efficiency, pure technical efficiency, and scale efficiency in each region decreased significantly. Therefore, when using the DEA model to calculate the actual efficiency, it is necessary to exclude the influence of environmental variables and random errors. ${ }^{27}$ From a regional perspective, the operating efficiency of funds in various regions differs significantly, 
showing a pattern of Central $(0.742)>$ Eastern $(0.689)>$ Western (0.505). The low technical efficiency of the Western region is mainly restricted by the low scale efficiency, and there is still a relatively low pure technical efficiency. Regression results indicated that there was a positive relationship between the economic development level, urbanization level, government public expenditure and the operating efficiency of the basic pension insurance. The old-age dependency ratio, however, showed the opposite effect.

This study has certain management enlightenment and guiding significance for improving the operating efficiency of China's basic pension insurance funds. In order to further optimize the allocation of operating resources and improve operating efficiency, we propose the following countermeasures and suggestions. Resource allocators should balance the allocation of relevant resources, and allow resources to be tilted to the Western and other areas on the basis of reasonable allocation, so as to maximize the use of resources. At the same time, the proportion and scale of resource allocation should be rationally planned with full consideration of factors affecting the elderly, such as the level of economic development, urbanization, government public expenditure and dependency ratio.

The government should improve the investment efficiency and broaden the investment channels of basic pension insurance funds. And, it is also necessary to improve the laws and regulations on the operation and management of basic pension insurance, improve the transparency in the use of funds, and strengthen disclosure obligations of managers and custodians. More importantly, the regulatory authorities also need to unify supervision of basic pension insurance funds, reduce decentralization management, and ultimately improve the overall operation efficiency of the basic pension insurance.

\section{Data Sharing Statement}

Please contact author for data requests.

\section{Ethical Approval}

All data are based on previous published studies, thus no ethical approvals are required. The outcomes of the analysis do not allow re-identification and the use of data cannot result in any damage or distress.

\section{Author Contributions}

All authors made a significant contribution to the work reported, whether that is in the conception, study design, execution, acquisition of data, analysis and interpretation, or in all these areas; took part in drafting, revising or critically reviewing the article; gave final approval of the version to be published; have agreed on the journal to which the article has been submitted; and agree to be accountable for all aspects of the work.

\section{Funding}

This study was funded by the Social Science Foundation of Anhui Provincial Education Department under Grant No. SK2020A0235; key Supporting Discipline of Public Administration of Anhui University of Chinese Medicine under Grant No. DC18100048; and Anhui Key Team Building Project of Young and Middle-aged Ideology and Politics under Grant No. SZTSJH2019-8-28.

\section{Disclosure}

The authors declare that they have no conflicts of interest for this work.

\section{References}

1. Sun L, Su C, Xian X. Assessing the sustainability of China's basic pension funding for urban and rural residents. Sustainability. 2020;12 (7):2833. doi:10.3390/su12072833

2. Hu Y, Wu Y, Zhou W, Li T, Li L. A three-stage DEA-based efficiency evaluation of social security expenditure in China. PLoS One. 2020;15(2):e0226046. doi:10.1371/journal.pone.0226046

3. Ebbinghaus B. Inequalities and poverty risks in old age across Europe: the double-edged income effect of pension systems. Soc Policy Adm. 2021;55(3):440-455. doi:10.1111/spol.12683

4. Grignon ML, Allin S, Corscadden L, Wolfson M. On measuring the inequity of financing health care in the United States and the redistribution of income through health care financing in Canada. Am J Public Health. 2020;110(11):1603-1604. doi:10.2105/AJPH.2020. 305891

5. Zhou Y, Tan K. Research on the redistribution effect of rural-urban residents' pension system reform - based on the changes of income disparity of the aged group. Popul Dev. 2021;27(1):86-95+116.

6. Yu W, Li B, Zhu X. Income redistribution effect of raising the overall planning level of basic endowment insurance for urban employees in China. Sustainability. 2021;13(2):709. doi:10.3390/su13020709

7. Wang H, Huang J, Yang Q. Assessing the financial sustainability of the pension plan in china: the role of fertility policy adjustment and retirement delay. Sustainability. 2019;11(3):883. doi:10.3390/ su11030883

8. Tian Y, Zhao X. Stochastic forecast of the financial sustainability of basic pension in China. Sustainability. 2016;8(1):46. doi:10.3390/ su8010046

9. Vukorepa I. Lost between sustainability and adequacy: criticalanalysis of the croatian pension system's parametric reform. Revija Za Socijalnu Politiku. 2015;22(3):279-308. doi:10.3935/rsp.v22i3.1307

10. Polidano $\mathrm{C}, \mathrm{Vu} \mathrm{H}$, Miller P, Otto G, Richardson M. Impacts from delaying access to retirement benefits on welfare receipt and expenditure: evidence from a natural experiment. Economic Record. 2020;96(312):65-86. doi:10.1111/1475-4932.12521

11. Chen X, Zhong S, Qi T. Delaying retirement and China's pension payment dilemma: based on a general analysis framework. IEEE Access. 2020;8:126559-126572. doi:10.1109/ACCESS.2020.3008 520 
12. Charnes A, Cooper WW, Rhodes E. Measuring the efficiency of decision making units. Eur J Oper Res. 1978;2(6):429-444. doi:10.1016/0377-2217(78)90138-8

13. Aigner D, Lovell CAK, Schmidt P. Formulation and estimation of stochastic frontier production function models. J Econom. 1977;6 (1):21-37. doi:10.1016/0304-4076(77)90052-5

14. Fried HO, Lovell CA, Schmidt SS, Yaisawarng S. Accounting for environmental effects and statistical noise in data envelopment analysis. J Product Anal. 2002;17(1-2):157-174. doi:10.1023/A:1013548723393

15. Li Z, Zhang W, Kong A, Ding Z, Wei H, Guo Y. Configuration analysis of influencing factors of technical efficiency based on DEA and fsQCA: evidence from China's medical and health institutions. Risk Manag Healthc Policy. 2021;14:49-65. doi:10.1108/CMS-04-2020-0151

16. Riumallo-Herl C, Aguila E. The effect of old-age pensions on health care utilization patterns and insurance uptake in mexico. BMJ Global Health. 2019;4(6):e001771. doi:10.1136/bmjgh-2019-001771

17. Zavras AI, Tsakos G, Kyriopoulos EJ. Using dea to evaluate efficiency and formulate policy within a greek national primary health care network. J Med Syst. 2002;26(4):285-292. doi:10.1023/A:1015860318972

18. Abruquah LA, Yin X, Ding Y. Old age support in urban China: the role of pension schemes, self-support ability and intergenerational assistance. Int J Environ Res Public Health. 2019;16(11):1918. doi:10.3390/ijerph16111918

19. Oikonomou N, Tountas Y, Mariolis A, Souliotis K, Athanasakis K, Kyriopoulos J. Measuring the efficiency of the greek rural primary health care using a restricted dea model; the case of southern and western greece. Health Care Manag Sci. 2015;19(4):1-13. doi:10.1007/s10729-0159324-4
20. Yang W. China's BEI performance evaluation based on SBM-DEA model. Adv Soc Sci. 2018;7(1):22-28. doi:10.12677/ASS.2018.71 003

21. Han J, Meng Y. Decreased contribution rates increase public pension fund revenue: evidence from china. $J$ Aging Soc Policy. 2021;33:120-137. doi:10.1080/08959420.2019.1707056

22. Khushalani J, Ozcan YA. Are hospitals producing quality care efficiently? An analysis using Dynamic Network Data Envelopment Analysis (DEA). Socio-Econ Plann Sci. 2017;60:15-23. doi:10.10 16/j.seps.2017.01.009

23. Sultan WIM, Crispim J. Measuring the efficiency of Palestinian public hospitals during 2010-2015: an application of a two-stage DEA method. BMC Health Serv Res. 2018;18:381. doi:10.1186/ s12913-018-3228-1

24. Flokou A, Aletras V, Niakas D. A window-DEA based efficiency evaluation of the public hospital sector in Greece during the 5-year economic crisis. PLoS One. 2017;12(5):e0177946. doi:10.1371/journal.pone. 0177946

25. $\mathrm{Xu} \mathrm{L,} \mathrm{Yin} \mathrm{Z}$, Yuan S. Thoughts on the relationship between endowment insurance and economic development under the background of urbanization. J Jiangxi Finance Coll. 2019;32(05): 41-47.

26. Zhang X, Song H, Wu B. Income, life expectancy and the income redistribution effect of social pension insurance. Stat Res. 2019;36 (3):78-87. doi:10.19343/j.cnki.11-1302/c.2019.03.007

27. Zhao C, Zhang H, Zeng Y, et al. Total-factor energy efficiency in BRI countries: an estimation based on three-stage DEA model. Sustainability. 2018;10(1):278. doi:10.3390/su10010278
Risk Management and Healthcare Policy

\section{Publish your work in this journal}

Risk Management and Healthcare Policy is an international, peerreviewed, open access journal focusing on all aspects of public health, policy, and preventative measures to promote good health and improve morbidity and mortality in the population. The journal welcomes submitted papers covering original research, basic science, clinical \& epidemiological studies, reviews and evaluations,

\section{Dovepress}

guidelines, expert opinion and commentary, case reports and extended reports. The manuscript management system is completely online and includes a very quick and fair peer-review system, which is all easy to use. Visit http://www.dovepress.com/testimonials.php to read real quotes from published authors. 